\title{
Crafting Sustainable Competitive Advantages Through Usage of Core Competences for Restaurant Chains in Vietnam
}

\author{
Son Tung Ha Manh Dung Tran \\ National Economics University, Vietnam
}

\begin{abstract}
In the recent years, food and beverage industry in general and restaurant businesses in particular have enjoyed a growth few other industries experiences. In that surge of scale, some businesses have proven to be successful while some other has suffered great losses, even though all of them seem particularly prone to succeed at the start. As entrepreneurs and investors rush to the industry, competition becomes fiercer than ever before. Sustainable competitive advantage becomes a survival requirement for any and all restaurant businesses. Using data from general statistics, this paper shall reveal the current landscape of restaurant chains in Vietnam. In order to rise above the pack and becomes a successful business, a restaurant chain in Vietnam needs to develop and nurture its sustainable competitive advantages, including location, price, quality of food and service and deep relationship with customers. Such competitive advantages are to be built from a business's core competencies, such as knowhow, high quality raw ingredients, close relationship with land owners etc.
\end{abstract}

Keywords: Restaurant chain, core competence, competitive advantage, Vietnam.

DOI: $10.7176 / \mathrm{JESD} / 10-7-02$

Publication date: April $30^{\text {th }} 2019$

\section{Introduction}

Chain restaurants are built to a standard format through architectural prototype development and offer a standard menu and/or services. Restaurant chain belongs to Food and Beverage (F\&B) sector including casual dining, family style, fine dining or high end, fast casual, fast food or quick serve restaurant, café, buffet, food trucks and ghost restaurant.

In Vietnam, the F\&B sector has boomed in the past decade, driven by not only foreign brands, but also local brands. According to figures from Business Monitor International (BMI) in its report on Vietnam's F\&B sector, growth in the industry is estimated at 9.43 per cent for the 2013-2017 period and will continue to rise in subsequent years. So far, Vietnam's F\&B sector consists of over 540,000 outlets including over 430,000 street stalls/kiosks; 7,000 fast-food restaurants; 80,000 full-service restaurants; 22,000 cafeterias/bars. They are present on every corner in every big city and offer consumers a diversified product portfolio, from very cheap to expensive, and from Western to Asian dishes.

The Ministry of Industry and Trade estimated Vietnam's annual consumption of food and drink products accounts for about 15 percent of Gross Domestic Products (GDP) and this rate will rise in the future. In addition, Vietnam is expected to enter the Top 3 Asian countries posting the highest growth rate of the F\&B industry by 2020. The strong GDP growth has fueled the development of the restaurant business in Vietnam due to the local culture of eating out. According to Decision Lab (2016), a Ho Chi Minh City-based market research firm, the outof-home consumption for food and beverage, are divided into a number of segments, of which full-service restaurants and quick service restaurants lead the group at 36 percent each. Among restaurant chains, fast-food chains and branded cafeterias/ bars have strongly grown in the last few years and are likely to continue to grow down the road. In terms of international brand name, from just a few brands ago such as KFC, Lotteria, Jollibee, or Pizza Hut, Vietnamese consumers nowadays have many more choices up to 71 foreign restaurant chains such as McDonald, Burger King, Domino’s, Carl's Jr, Popeyes, Baskin Robins, Texas Chicken, Subway, Starbucks, Holly, the Coffee Bean and Tea Leaf etc. and a lot more local restaurant chains such as Mon Hue, Vuvuzela, Kichi Kichi, Koh Sahmui, or Trung Nguyen. The population is growing at a rate of about 1\%, meaning nearly 1 million new customers are born every year, making the country extremely attractive to anyone in the F\&B sector. To catch that trend and achieving lasting success in the market, some of restaurant chains are creating sustainable competitive advantages, some of them are not. Frankly to say, sustainable competitive advantage is a key determinant of superior performance, and ensures survival and prominent placing in the market. Superior performance is the ultimate, desired goal of a firm; competitive advantage becomes the foundation. Thus, sustainable competitive advantages are very important to restaurant chains. In that light, this paper aims at: (i) briefing review about sustainable competitive advantages and the relationship between sustainable competitive advantages and core competences; (ii) providing overview of restaurant chains in Vietnam; and (iii) proposing recommendations in crafting sustainable competitive advantages through the use of core competences for restaurant chains in Vietnam. 


\section{Literature review}

The search for sustainable competitive advantage has been the dominant theme in the study of strategy for many years (Bain, 1956; Kay, 1994; Porter, 1991). Understanding of this term needed to separate between competitive advantage and sustainable competitive advantage. Competitive advantage describes the advantage a company has over other firms, which compete in the same market (Burn, 2008). It can be explained as the resources and features of a company that helps it to do better than their competition (Sharp, 1991). Competitive advantage results from a firm's ability to perform the required activities at a collectively lower cost than rivals, or perform some activities in unique ways that create buyer value and hence allow the firm to command a premium price (Porter, 1991). It's the attributes that a company can deliver over its competitors in terms of both tangible and intangible assets. A competitive advantage can be any innovation, product, service, patent or anything else that differentiates the company in a positive way from the rest of the competition. Competitive advantage is at the heart of firm's performance. It is concerned with the interplay between the types of competitive advantage, i.e cost, differentiation, and the scope of the firm's activities (Kak et al., 2002). Competitive advantages have evolved through the time.

The "word" sustainable contributes the necessary time component to the concept of competitive advantage. Sustainability considers the protection of resources over a period of time into the future for the organizations to maintain its competitiveness. Sustainability within the context of competitive advantage is considered in terms of the organization positively embracing change, constantly adapting to altered ways and new demands through introducing new resource configurations, while at the same time preserving the best of its past. Grant (1995) considers the sustainability of the competitive advantage along the dimensions of durability, mobility and replicability. Durability determines how long the competitive advantage can be sustained and is considered in terms of the ability of competitors to imitate through gaining access to the resources on which the competitive advantage is built. Environmental sustainability and social responsibility also emerge as attributes for a sustainable competitive advantage. Environmental practices contribute to the reduction of inputs used in production, better quality and lower production costs, as well as less environmental pollution (Severo et al., 2015).

Aaker (1998) researched on sustainable competitive advantage on 248 businessmen in various industries range from services to high-tech and so on. The result showed that different types of business requiring different types of sustainable competitive advantages. Even in the same industries, different business also requires different sustainable competitive advantages. Thus, sustainable competitive advantage is a journey and not a destination it is like tomorrow which is inescapable but never arrives. Sustainable competitive advantage only becomes meaningful when this journey is experienced (Chaharbaghi \& Lynch, 1999). A sustainable competitive advantage creates some barriers that make imitation difficult. Without a sustainable competitive advantage, above average performance is usually a sign of harvesting (Porter, 1985).

"How to achieve sustainable competitive advantage?" is one of the most important questions that any firm needs to answer for. Firms are continuously striving for ways to attain sustainable competitive advantages. To obtain sustainable competitive advantages, firms need to frame core competencies. They need to count more on their internal distinguished strengths to provide more added customer value, strong differentiation and extendibility; in other word count more on their "core competences". Core competences as the collective learning and coordination skills behind firm's product lines. Core competencies are the source of competitive advantage, and enable a firm to introduce an array of products and services in the market (Hamel and Prahalad, 1990). A core competency is about the knowledge on successes or failures in recommending knowledge resources (Banerjee, 2003); or it is the ability to operate efficiently within the business environment and to respond to challenges (Chen $\& \mathrm{Wu}, 2007)$. So, core competences are unique capabilities that widespread in the corporation and span over multiple products. Bani-Hani and AlHawary (2009) indicated that a core competence is the knowledge set that distinguishes a firm and provides a competitive advantage over others. Core competences include all assets, capabilities, organizational processes, firm attributes, information, knowledge, etc. Gupta et al. (2009) pointed out that resources alone are frequently not enough to generate competitiveness over other firms. In creating a competitive advantage, a firm needs the ability to make good use of resources - defined as the capability to handle a given matter - and, as the ability grows over time, to utilize the available resources to create new resources, such as skills (through new technology or software application), or to open new doors to the development of new types of product.

There is a significant positive relationship between core competences and sustainable competitive advantage. Core competence is considered to be a source of sustainable competitive advantage in the dynamic business environment, through the constant renewal of core competencies to create sustainable competitive advantage. In the longer run, an organization's ability to survive and grow depends on sustainable competitive advantages, which have their roots in the organizational core competencies that represent the collective learning and flexibility (Kak et al., 2002).

Barney (1991) stated that not all firm resources hold the potential of sustainable competitive advantage; instead, they must possess four attributes: rareness - the price of the resource will be a reflection of the expected 
discounted future above-average returns; value - either outperforming its competitors or reducing its own weaknesses; inability to be imitated - be sustainable if competitors are not able to duplicate this strategic asset perfectly, and inability to be substituted - an equally important aspect is lack of substitutability. From which, firms should systematically work upon identifying their core competencies, recognizing and developing them for sustainable competitive advantages. In that light, many researches has confirmed that in order to sustain competitive advantage it should protect itself from being despoiled and assimilate new sources of technologies, skills and core competencies (Hamel and Prahalad, 1990, Fisher, 1989). Of course, core competences of business are different from industries to industries. As a business grows, develops and adjusts to the new environment, so do its core competencies also adjust and change. Thus, core competencies are flexible and developing with time.

\section{Vietnam restaurant chain overview}

Restaurant chains in Vietnam have expanded rapidly over the last ten years, together with the growth of the F\&B sector. International brands and local ones have fueled the very promising Vietnamese market.

There are many famous local Vietnamese food restaurant firms such as Huy Vietnam which is operating about 140 restaurants including famous brands such as Mon Hue with 60 outlets, Pho Ong Hung with 33 outlets, Com Tho Chay with 13 outlets (previously branded Com Express); Golden Gate with more than 316 restaurants with 22 famous brands including Gogi House, Sumo BBQ, Cowboy Jacks, Vuvuzela, etc.; Redsun ITI, a member of the Goldsun Group now operates 12 restaurant brands including Thai Express, Seoul Garden, King BBQ or Hotpot story and 140 restaurants across the country. Some well-known international brands continue rising as storms such as KFC with 140 restaurants, Burger King with 20 restaurants, Pizza Hut with 50 restaurants, Mc Donald with 8 restaurants, Domino's Pizza with 24 outlets, Coffee Bean and Tea Leaf with 16 outlets, MOF (Ministry of Food) with 9 outlets, Angel-in-us Coffee with 5 outlets or Cafe Benne with 5 outlets, etc. Of course, there are a lot more local and foreign brands with all the size existing in the market.

Recently, foreign funds have poured millions of dollars in restaurant chains in Vietnam. Undeniably, investment in dining chains is a developing trend. It is not much affected by economic downturns since food is indispensable. Thus, this sector in Vietnam will always be attractive to investors.

Through the time, numbers of investment have increased. Thanks to that, its earnings skyrocketed to reach VND 1.2 trillion (\$52.7 million) in 2014 and went on to triple that amount to Vietnamese dong (VND) 3.3 trillion (\$145 million) in 2017. In 2014, Golden Gate received an infusion of \$35 million from Standard Chartered. Earlier Vietnamese private equity firm Mekong Capital said it had exited from Golden Gate with a net 9.1-fold return on its investment. Mekong Capital reportedly invested \$2.6 million in Golden Gate in 2008, and two years later started to partially sell off its holding. In 2015, Institutional investors in Singapore and Hong Kong invested US \$15 million into Huy Vietnam Group and it got an infusion of \$11 million from US fund Franklin Templeton. Franklin Templeton prioritizes investment in firms with good management, efficient business and transparent information. In 2016, Mekong Enterprise Fund III invested \$6.9 million into the company owning the Wrap \& Roll restaurant chain. Then, Wrap \& Roll invested into Ut Ut and Beer Craft with plans to expand the chain to ten restaurants. Kafe Group, which runs a coffeehouse chain in Vietnam, received an investment of USD 5.5 million from institutional investors in London and Hong Kong. Hong Kong-based Cassia Investments, a private-equity firm specializing in funding lower middle-market firms across Asia, has provided 90 percent of the funding. The other 10 percent came from another investor based in London.

The market has witnessed some big wins and some huge losses as well. Restaurants come and go all the time. Tough competition has forced the Australia's Gloria Jean's Coffees out. Arrived in Vietnam in 2006 but the last store of this brand was forced to close in 2012. New York Dessert Cafe (NYDC) said goodbye to its customers in Vietnam after 7 years of doing thought it used to be one of the most popular foreign coffee chains in Ho Chi Minh City (HCMC). In 2011, Pho 24, a high-end restaurant chain which once dominated the Vietnamese food chain business with 60 restaurants in the country and 20 restaurants overseas, finally agreed to the acquisition by Viet Thai, the owner of the Highland Coffee chain. In fact, after the ownership change, the number of Pho 24 restaurants fell to 16 in Ho Chi Minh City and a single restaurant in Hanoi's Noi Bai International Airport, according to its website (Vietnam: Home disadvantage in franchising, 2019). Koh Samui Thai's food has "silently" left 2 out 5 restaurants. The Kafe coffee chain was officially closed though it was funded by foreign funds. Burger King has closed five restaurants in Ho Chi Minh City, Hanoi, and Danang in recent years, citing sub-optimal location. McDonald now has only 17 restaurants, falling rather short of the target in the planning to open 100 restaurants in Vietnam within the decade. Burger King debuted in 2012 with an ambitious plan to build 60 stores in 5 years. However, recently, the company closed several restaurants and in February, its network had only 16 restaurants. Here are just a few typical illustrations in Vietnam.

These restaurant chains can fail for a whole host of reasons. Parsa et al. (2005) that restaurant failures can be studied from economic, marketing, and managerial perspectives. Of these three perspectives, restaurant failures have been studied primarily from the economic perspective. In Vietnam, competition in the food chains can be understood as the invisible war between modern fast food chains and hundreds of thousands of family-sized food 
shops in Vietnam. One of the advantages of local brand is the ability to satisfy strict requirement of local diners on traditional tastes. It is difficult for international brands to adjust ideas and concepts to suit the culture of Vietnam, while domestic brands are already appropriated to local people's habit of eating (Wang et al., 2014).

A new report from Vietnam-based research firm Decision Lab has revealed dining habits by Vietnamese consumers. With which, locals are also more likely to visit a Western-style restaurant in larger groups and for special occasions. And a convenient location was the leading reason for choosing a restaurant, above the quality and taste of the food (Davis, 2016). Those are in line with the research from Decision Lab of out-of-home Food and Drink consumption trends Vietnam in 2016 that when it comes to eating out, reasons for restaurant choice are shown in the figure 1:

\section{Top reasons for choosing Western and Asian Outlets}

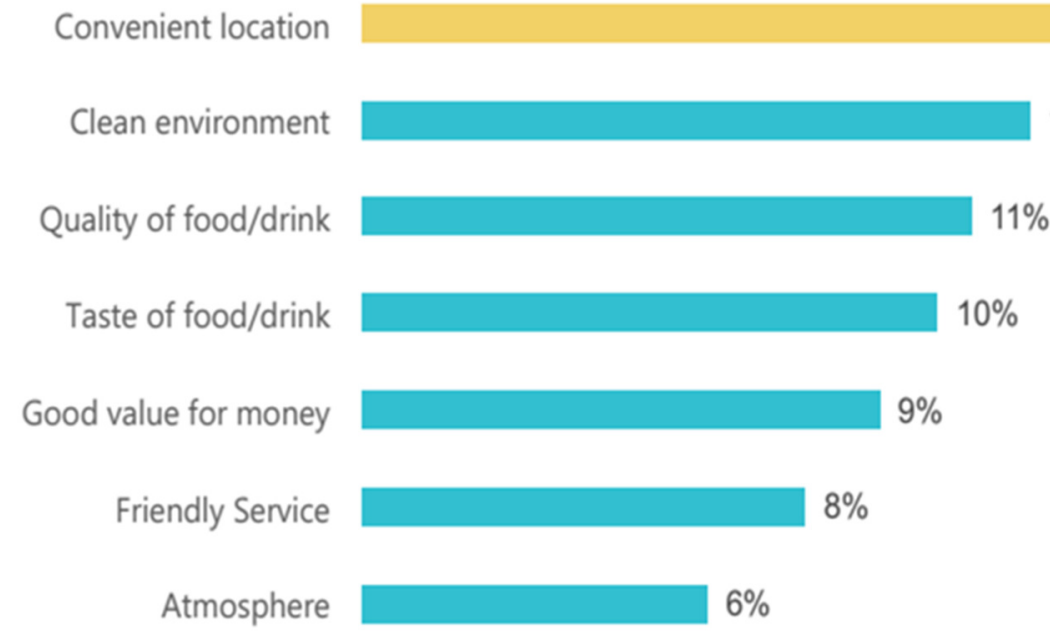

Figure 1. Reasons for restaurant choices

The result shows that most of people in Vietnam choose restaurant because of location (16\%). It is followed by another $12 \%$ of clean environment, $11 \%$ of quality of food/drink, $10 \%$ of taste of food/drink and $8 \%$ of good value for money. Indeed regardless of type of food the restaurant serves, it must be in a location that is accessible by the target market. Though online delivery is growing strongly, location is still a strong factor for success of restaurant chains in Vietnam. Related to clean environment and quality food/drink aspects, the above results are in line with the research of Nguyen et al. (2018) that the cleanliness of facilities and food processing places was the most common factor. Meanwhile, customers reported perceiving the hygiene and safety of food as the most important factor of a food facility. Besides, good value for money could be explained that consumers with higher income will also look for higher quality and higher value products and, retailers will respond by offering a wider range of premium food and drinks alongside other non-essential products and imported foreign brands; consumers with lower incomes will continue to spend on less expensive products, as their finances dictate. Retailers will therefore need to continue to offer low cost, budget and discount products to satisfy consumers' sensitiveness on pricing (Nguyen, 2018).

In addition, the research from Decision Lab in 2016 revealed that restaurants are not just competing within their channel and cuisine, competition comes from everywhere including street food. Competition is fierce with many outlets offering good quality food at low prices. An illustration for this disclosed by a report from Insider Retail that two factors led to the failure of NYDC (New York Dessert Coffee) Vietnam as (i) a series of local coffee chains like The Coffee House, Phuc Long, Urban Station, Trung Nguyen, Kafe and Highlands Coffee are expanding with affordable prices and comfortable spaces as their advantage; (ii) international chains like Starbucks have appeared.

Therefore, in today's ever-changing and unpredictable environment, both international and local Vietnamese restaurant chains need to find and realize their own unique core competencies in order to build a portfolio of sustainable competitive advantages.

\section{Recommendations}

First, in terms of convenient location, it is something that is easier to be said than achieved. Real estate pricing often varies greatly between locations, even between two end of the same streets. In order to afford a location that is situated in a busy, eye-catching area like large supermarkets, main streets or tourist destinations with the promise of a higher foot fall from customers, a restaurant chain needs to have huge capital and close relationship with the 
land owner as core competencies. While the monthly rent is already high enough, land owners often require lessor to pay a minimum rental fee of 6 months to 1 year, excluding deposits. In some not uncommon cases, in order to retain a good location from being scooped up by other businesses, lessor has to pay lump sum for several years of rent contract. The amount of capital required is often into the billions Vietnam dong. For instance, Golden Gate restaurant chain spends about 440 billion VND (around 18.9 million USD) annual renting fee for about 316 restaurants; McDonald's has paid 12 billion VND (around 517,000 USD) annual renting fee for 1 restaurant. According to CBRE Vietnam report in 2018, retail rental prices in central business districts (CBDs) of HCMC reach US\$121.6 per square meter per month, that of Hanoi reach US \$99 per square meter per month. Therefore, having a substantial source of capital is important to maintain and sustain location as a competitive advantage. This is in line with the finding of Suga (2017) that financial sustainability was necessary to maintain any other form of operation; therefore, it is found to be the necessary backbone to any other core activities in any food business. Another problem that is happening more and more regularly nowadays is that the land owners sometimes ask for the premise back while business is running well, either as a bargaining tactics, or they want to get the premise back to run the same business themselves. To some extent, the retail rent is not related to the business performance of the shops. The rent tends to increase because of the growing tendency of opening food shops (Vietnam: Vietnam's street food popular items now being served at chain restaurants, 2017). This is more commonly faced by smaller chains with less bargaining power. As a result, building a good relationship with the land owner is also a key factor in maintaining location as a competitive advantage.

Second, to sustain quality or taste of food as one of the competitive advantage of restaurant chains in Vietnam, international brands or local ones must pay more attention to know-how, a unique concept, innovation or highquality raw ingredients as core competencies. In this light, successful cases in Vietnam are McDonald's, Lotteria, Subway or KFC. Indeed, 80 percent of the materials used by Lotteria Vietnam over the last 15 years are made in Vietnam, but by the joint ventures between Vietnamese and foreign partners, not 100 percent domestic owned producers. At McDonald's Vietnam, only tomatoes and salad are from Vietnam - they are bought from Da Lat, while 100 percent of meat is imported from Australia, pork and potatoes are from the US. Even the paper cups or paper food boxes are also imported from neighboring countries like China or Malaysia. Subway Vietnam has to import most of the materials needed to make sandwiches, except some vegetables from Da Lat City, Vietnam. In terms of know-how and innovation, to make a better quality, all KFC cooks must experience a severe training course to ensure the unique flavor and the quality of nutrition for their dishes, according to the group's standards. According to its website, the recipe of 11 herbs and spices used by KFC in preparation of their chicken remains a secret trade, which helps to create a special flavor for their products. In terms of unique concepts, according to the Decision Lab's Out-of-Home, Food \& Drink Consumption Trends Vietnam Report in 2016. Asian restaurant such as Vietnamese, Thai, Japanese, and Korean clearly dominate the market with the share of 53\%. On the other hand, only $7 \%$ of restaurants are Western - American, French, Italian, etc. It also means that the restaurant chains in Vietnam need to pay more attention on the concept delivering their products. Whether it is an Asian or Western food, a unique concept is important as it will help set the tone of the business. To some extent, staff, including employees' training, personality, and diversity is another critical core competence adding on sustainability of quality or taste of food.

Third, to lower the price, restaurant chains can lower overhead costs in processing, labor, enhance the relationship with local suppliers. Having good relationship with suppliers not only helps restaurant chains reduce price of raw materials but also create more positive effects on the environment and local or rural development as food transportation contributes significantly less to overall greenhouse emissions compared to food production (Weber et al., 2008). Furthermore, to reduce the price, there are some other ways that restaurant chains can handle to achieve economies of scale such as bulk processing ingredients into precisely identical units of production; experience-curve efficiencies, which are cost advantages gained over time as a firm's knowledge grows and the cumulative number of units produced increases.

Fourth, to achieve sustainable competitive advantages as quality, clean environment and price, one of the most crucial core competences is managing capability. Indeed, many restaurant chains in Vietnam have failed because of which such as Pho24, The Kafe, Koh Samui, Urban Station, etc. Increasing in volume of restaurants in chains results in challenges in management. There are a lot of challenges in chains arise every day such as managing relationships between territories, demographic groups, social codes of specific ethnic or religious groups because of cultural distance. Thus, ensuring products and services are manufactured correctly, cost effectively and is significant. If these issues cannot be controlled, it would affect directly the whole system. As a result, embracing new technology across the business is necessarily. By utilizing management software, mobile application, etc., owners can manage guest flow, enhance customer engagement within the store, seat configurations, service delivery times and inventory in every restaurant in chain. Also, to offer clean environment, managers need to have a general view to detailed items of hygiene in restaurants in order to ensure that all areas of the restaurants are clean. For example, tables, chairs, toilets, floors, furniture, sidewalks, ceilings, walls, .etc. need to be noticed (Wang et al., 2014). 
Fifth, as mentioned above, environmental sustainability and social responsibility also emerge as attributes for a sustainable competitive advantage. Restaurant chains need to engage with the local community through event sponsorship, take more initiatives in protecting the environment other than just simply paying attention to the bottom line. This can help raise awareness of the business and its brand and in this aspect, it is a very strong tool of marketing and public relations. When a business puts people first and focuses on making positive changes for the communities it works with and serves, consumers would notice. These also mentioned in the previous research of Ponsonby-McCabe (2006) that firm-specific and difficult to imitate, the brand usually captures the identity of a restaurant and constitutes a key value-creating resource.

Table 1 below is a summary of how core competencies and sustainable competitive advantages are linked for restaurant chains in Vietnam.

Table 1: Connecting core competences and competitive advantages of restaurant chains

\begin{tabular}{|l|}
\hline Core Competences \\
\hline Know-how \\
\hline High-quality raw ingredients \\
\hline Managing capability \\
\hline Capital \\
\hline Clowe relationship with land owners
\end{tabular}

In short, sustainable competitive advantages are the key success factor for restaurant chains. Most restaurant chains choose either one of a combination of price, quality, service and location as competitive advantages. To make these competitive advantages more sustainable, restaurant chains must pay attention to finding/recognizing appropriate core competences. Core competences for restaurant chains in Vietnam could be know how, close relationship with suppliers, managing capability, experience, high technology, capital or close relationship with land owners. Certainly, competitive advantages and core competences of each restaurant chain might be different and unique for each restaurant brand. However, it is important to realize what they have as their core strength to turn them into sustainable competitive advantages.

\section{References}

Aaker, D. A. (1998), Strategic Market Management, $5^{\text {th }}$ Ed., John Wiley and Sons.

Bani-Hani, J. S., and AL-Hawary, F. (2009), The Impact of Core Competences on Competitive Advantage: Strategic Challenge. International Bulletin of Business Administration, 6, 93-104.

Bain, J. (1956), Barriers to New Competition: Their Character and Consequences in Manufacturing Industries, Harvard University Press, Cambridge, MA.

Barney, J. (1991), "Firm resources and sustained competitive advantage", Journal of Management, 17(1), 99-120.

Banerjee, S. B. (2003), Who Sustains Whose Development? Sustainable Development and the Reinvention of Nature. Organization Studies, 24, 143-180.

Chaharbaghi, K., Lynch, R. (1999), Sustainable competitive advantage: towards a dynamic resource-based strategy, East London Business School, MCB University Press.

Chen, Y.F and Wu, T.C. (2007), An empirical analysis of core competence for high-tech firms and traditional manufacturers. Journal of Management Development, 26(2), 159-168.

Davis, B. (2016), How Vietnam's Dining Habits Are Changing with International Brands, retrieved on 6th August 2017, from https://www.forbes.com/sites/davisbrett/2016/10/27/how-vietnams-dining-habits-are-changingwith-international-brands/\#6258b816905e

Fisher, G. (1989), Competing Beyond Technology: Customers Drive a Technology driven company. Harvard Business Review, Nov-Dec, 107-114.

Grant, R. (1995), Contemporary Strategy Analysis, Blackwell, Cambridge, MA. 
Gupta, S., Woodside, A., Dubelaar, C., and Bradmore, D. (2009), Diffusing knowledge-based core competencies for leveraging innovation strategies: Modeling outsourcing to knowledge process organizations (KPOs) in pharmaceutical networks. Industrial Marketing Management, 38, 219-227.

Hamel, G. and Prahalad, C.K., (1990), "The Core Competence of the Corporation", Harvard Business Review, May-June, 79-91.

Kak, A,. and Sushil, A. (2002), Sustainable competitive advantage with core competence: A review, Global Journal of Flexible Systems Management, 3(4), 23-38.

Kay, J. (1994), Foundations of Corporate Success, Oxford University Press, Oxford.

Nguyen, L. (2018), Vietnam -2018 food and beverage, the Business Centre of The British Business Group Vietnam (BBGV), retrieved on 14th March 2019, from https://bbgv.org/wp-content/uploads/2018/06/Vietnam-FoodDrink-Sector-Brief-BBGV-July2718.pdf

Nguyen, A.T.L, Tran, X.B., Le, T.X.T., Do, K.N., Vu, G.T., Nguyen, L.H, Latkin, C.A., \& Ho, C.A.L. (2018), Customers' Knowledge, Attitude, and Practices towards Food Hygiene and Safety Standards of Handlers in Food Facilities in Hanoi, Vietnam, Int. J. Environ. Res. Public Health, 15(10), 1-9. doi:10.3390/ijerph15102101.

Parsa, H. G., John T. S., David, N. and King, T. (2005), Why Restaurants Fail, Cornell Hotel and Restaurant Administration Quarterly, 46(3), 304-322. DOI: 10.1177/0010880405275598.

Ponsonby-McCabe, S. (2006), Understanding brands as experiential spaces: Axiological implications for marketing strategists. Journal of Strategic Marketing, 12, 175-89.

Porter, M.E. (1985), Competitive Advantage: Creating and Sustaining Superior Performance, The Free Press, New York.

Porter, M.E. (1991), Towards a Dynamic Theory of Strategy, Strategic Management Journal, 12 (Special Issue: Fundamental Research Issues in Strategy and Economics), 95-117.

Severo, E.A., Guimaraes, J.C.F., Dorion, E.C.H., \& Nodari, C.H. (2015), Cleaner production, environmental sustainability and organizational performance: an empirical study in the Brazilian metal- mechanic industry. Journal of Cleaner Production, 96, 118-125.

Sharp, B. (1991), Competitive Marketing Strategy: Porter Revisited. Marketing Intelligence \& Planning, 9(1), 410 .

Suga, R., (2017), Key Value Drivers for Sustainable Restaurant Business Models, retrieved on $6^{\text {th }}$ Feb 2019, from https://www.modul.ac.at/uploads/files/Theses/Bachelor/undergrad 2017/Thesis 1311002 SUGA Robert. pdf

Wang, W. L., Tran, T. T, Nguyen, T. N. (2014), Analyzing factors to improve service quality of local specialties restaurants: A comparison with fast food restaurants in Southern Vietnam, Asian Economic and Financial Review, 4(11), 1592-1606.

Weber, C. L., \& Matthews, H. S. (2008), Food-miles and the relative climate impacts of food choices in the United States. Environmental science \& technology, 42(10), 3508-3513. 